\title{
Model Desain Apotik Hidup bagi Keberlanjutan Pemanfaatan Pengolahan Sampah Organik Rumah Tangga di Desa Ciangsana, Kabupaten Bogor
}

\author{
A Living Apothecary Design Model for Sustainability of Household Organic Waste Processing \\ in Ciangsana Village, Bogor District
}

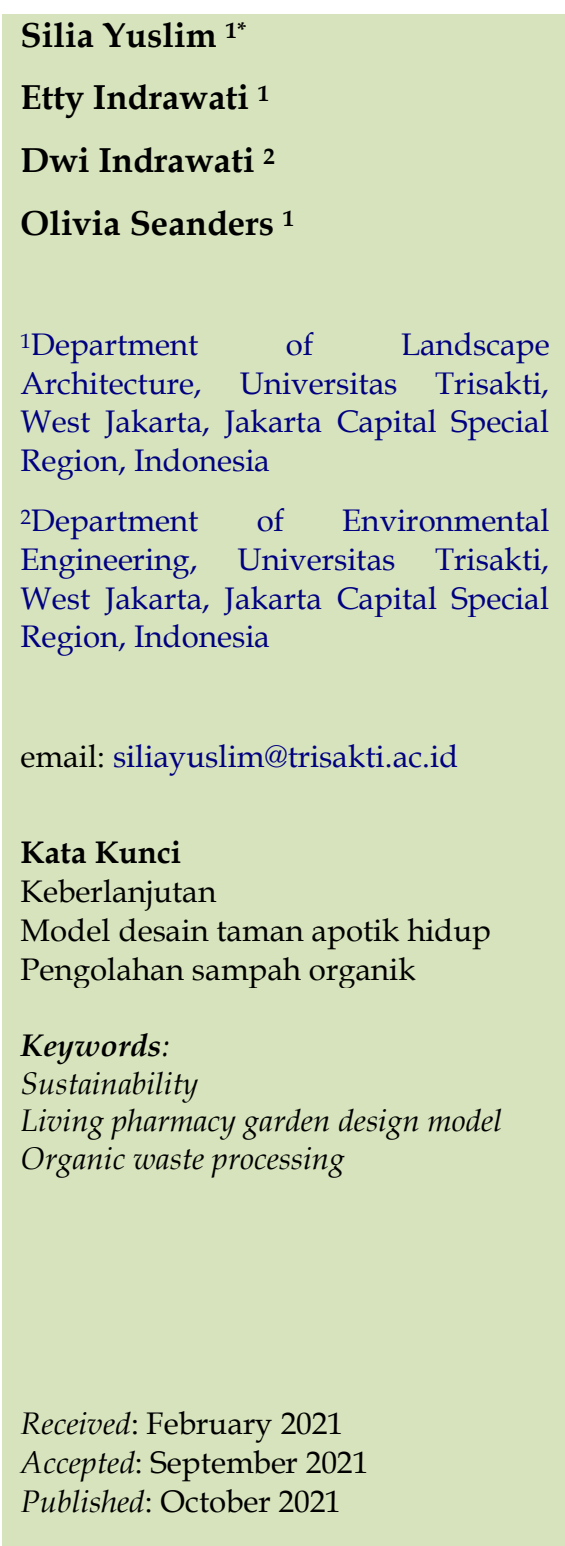

\begin{abstract}
Abstrak
Desa Ciangsana, kecamatan Gunung Putri, kabupaten Bogor telah melakukan pengelolaan sampah secara mandiri. Terdapat dua Bank Sampah di sana, yaitu Bank Sampah Cantik di RW 20 dan Bank sampah Cinta di RW 21. Keberadaan bank sampah ini juga telah memicu masyarakat setempat untuk mengolah sampah dapur yang bersifat organik secara mandiri, namun hasil pengolahan yang berupa kompos memerlukan pemanfaatan lebih lanjut untuk menjaga keberlanjutannya, terutama di RW 20. Program Pengabdian kepada Masyarakat (PkM) jurusan Arsitektur Lanskap akan melakukan koordinasi dan konsultasi untuk membuat model desain taman apotik hidup pada lahan di sekitar Bank Cantik serta menjelaskan proses pembuatan dan proses penataannya menjadi sebuah taman dalam kegiatan penyuluhan. Manfaat yang dirasakan dari kegiatan Pkm ini dilihat berdasarkan kuesioner yang disebar kepada peserta Pkm, yaitu perwakilan pengurus Bank Sampah, ibu-ibu PKK, dan pengurus RW (ketua dan sekretaris RW). Hasil dari PkM ini, terlihat bahwa dari seluruh pernyataan yang dijawab peserta, 96\% menggambarkan bahwa pembuatan model sangat bermanfaat bagi peserta, namun ada satu peserta yang tidak memerlukan pendampingan dalam pengaplikasian model desain di lapangan.
\end{abstract}

\begin{abstract}
Ciangsana Village, Gunung Putri sub-district, Bogor district has carried out independent waste management. There are two waste banks there, the Cantik waste banks in RW 20 and the Cinta Waste Bank in RW 21. This waste bank has also spurred local communities to process organic kitchen waste independently, but the processing results in the form of compost require more use. Continue to maintain its sustainability, especially in RW 20. The Community Service Program (PkM) majoring in Landscape Architecture coordinate and consult to create a living apothecary design model on the land around Bank Cantik and explain making it and structuring it into a park in activities counseling. The benefits felt from this PKM activity can be seen based on a questionnaire distributed to PKM participants: representatives of the Waste Bank management, PKK women, and RW management (RW heads and secretaries). The results of this PkM show that of all the participants' statements, $96 \%$ described that modeling was beneficial for the participants. Still, one participant did not need assistance in applying the design model in the field.
\end{abstract}

(C) 2021 Silia Yuslim, Etty Indrawati, Dwi Indrawati, Olivia Seanders. Published by Institute for Research and Community Services Universitas Muhammadiyah Palangkaraya. This is Open Access article under the CC-BYSA License (http://creativecommons.org/licenses/by-sa/4.0/). DOI: https://doi.org/10.33084/pengabdianmu.v6i6.2163

\section{PENDAHULUAN}

Desa Ciangsana, merupakan daerah penyangga DKI Jakarta. Desa ini merupakan salah satu desa yang berada di Kecamatan Gunung Putri, Kabupaten Bogor dengan luas wilayah $861.722 \mathrm{Ha}$, yang terdiri dari $859.722 \mathrm{Ha}$ dan 2 Ha sawah, serta terbagi dalam 8 kepala dusun dan 48 
RW. Dalam wilayah desa ini telah dilakukan pengelolaan sampah. secara mandiri. Terdapat dua RW yang mengelola bank sampah, yaitu RW 20 dengan Bank Sampah Cantik dan RW 21 dengan Bank Sampah Cinta. Program PkM dilakukan di RW 20 yang memiliki 14 RT, dengan jumlah Kepala Keluarga sebanyak 600 KK dan berada di Kompleks TNI AL

Bank Sampah Cantik tidak hanya mengelola sampah anorganik, juga mengelola sampah organik. Setiap keluarga juga melakukan pengolahan sampah organik untuk dijadikan kompos. Untuk menjaga keberlanjutan hasil pengolahan sampah organik yang berupa kompos dapat dilakukan dengan cara memafaatkannya digunakan sebagai campuran media tanam. Hal ini dilakukan pada halaman pekarangan masyarakat setempat dengan menjadikan perkarangan sebagai taman apotik hidup, warung hidup, atau taman yang berisi tanaman hias (Dahlianah, 2015). Terkait dengan hal tersebut, program PkM ini memberikan model desain taman apotik hidup pada lahan yang terdapat di sekitar lokasi Bank Sampah Cantik. Upaya ini juga dilakukan mengingat biaya kesehatan yang relatif semakin meningkat, karena harga obat-obatan yang cukup mahal dan tidak terjangkau bagi masyarakat kota, khususnya bagi masyarakat dengan kondisi ekonomi lemah (Sumarni, 2013). Oleh karena itu, keberadaan obat herbal yang dihasilkan dari tanaman obat yang dapat tumbuh di kawasan perkotaan dapat menjadi alternatif solusi yang dapat disarankan (Mulyani et al., 2016). Sejalan dengan penelitian yang menyatakan bahwa pengobatan tradisional lebih murah dibandingkan pengobatan medis, serta bahwa obat tradisional memiliki efek samping yang lebih kecil/sedikit (Djabbar et al., 2017).

Sebenarnya, sudah sejak lama masyarakat Indonesia mengenal berbagai bentuk taman di pekarangan atau halaman rumah. Taman dapat berupa taman bunga, taman warung hidup dan karangkitri atau apotik hidup.
Taman karangkitri atau taman apotik hidup merupakan taman yang ditanami dengan tanaman obat, yang saat ini dikenal dengan nama Tanaman Obat Keluarga (TOGA) (Gunarto, 2012). Program PkM ini juga mendukung program pemerintah untuk memanfaatkan tumbuhan obat, diantaranya dengan pengembangan TOGA, agar dapat lebih mendekatkan tanaman obat pada pelayanan kesehatan masyarakat dan sebagai salah satu langkah yang tepat untuk pelestarian tanaman obat yang merupakan sumber obat tradisional yang telah terbukti berkahasiat dan aman digunakan dalam pencegahan, pegobatan, perawatan, dan pemeliharaan kesehatan, seperti yang dinyatakan dalam Undangundang Kesehatan RI No.36 Tahun 2009 pasal 100.

Tujuan dari pembuatan model desain taman apotek hidup ini adalah untuk memberikan wawasan dan pemahaman pada masyarakat setempat, terutama ibuibu PKK dan pengurus Bank Sampah Cantik. Penanaman tanaman obat juga dapat ditata dan dikelola (pemanfaatan pupuk/kompos hasil pengolahan sampah organik) dengan baik untuk memberikan hasil yang optimal, mudah dalam pemeliharaan dan terlihat indah. Selain itu, dengan pembuatan model desain ini, diharapkan masyarakat setempat dapat menata kembali lahan yang dirancang dengan berpedoman pada gambar desain tersebut, serta dapat menjadikannya contoh bagi penataan taman apotik hidup di pekarangan rumah masing-masing. Dengan demikian, tanaman obat yang dikembangkan, pada suatu saat bukan saja dapat dilestarikan dan memperbaiki gizi keluarga, namun juga dapat menjadi sumber pendapatan masyrakat (KaroKaro, 2010; Hikmat et al., 2011).

\section{METODOLOGI}

Khalayak sasaran dari program PkM ini adalah pengurus Bank Sampah, pengurus RW (Ketua dan Sekretaris RW), dan ibu-ibu PKK yang berjumlah 20 
orang. Khalayak sasaran ini merupakan penggerak masyarakat sekitar, sehingga diharapkan dapat menjadi pembina bagi masyarakat sekitar. Kegiatan program PkM ini diawali dengan melakukan survey lokasi, penyuluhan, dan penyebaran kuesioner. Rincian dari kegiatan yang dilaksanakan dalam program PkM ini adalah sebagai berikut:

1. Survey lokasi, dilakukan untuk memilih tapak yang akan dijadikan model percontohan dari desain taman apotik hidup, kemudian dilakukan pengukuran serta pendataan tarhadap tanaman obat eksisting. Selain itu, dilakukan wawancara dan diskusi dengan khalayak sasaran untuk mendapatkan data tentang kebutuhan masyarakat sekitar terhadap tanaman obat yang diprioritaskan untuk ditanam. Ini dilakukan untuk memudahkan pembuatan desain taman apotik hidup.

2. Sosialisasi tentang materi yang terkait dengan proses pembuatan model taman apotik hidup dan penjelasan terkait gambar model desain taman apotik hidup, yaitu:

a. tahapan proses pembuatan desain taman apotik hidup yang mengacu pada proses perancangan lanskap, (Simonds \& Starke, 2006), terdiri dari inventarisasi data (diperoleh dari hasil survey), analisis, sintesis, perancangan, pelaksanaan dan pemeliharaan;

b. unsur-unsur pembentuk suatu desain lanskap, (Mulyadi, 2011), terdiri dari permukaan tanah, tanaman, perabot taman, perkerasan dan air;

c. prinsip-prinsip desain lanskap, yang diperlukan dalam menata komposisi tanaman obat sehingga taman apotik hidup dapat tumbuh secara optimal, mudah dipelihara, dan indah untuk dipandang. Menurut Mulyadi (2011), prinsipprinsip desain lanskap terdiri dari kesatuan (unity), keseimbangan (balance), penekanan (emphasis), irama (ritme), kontras dan proporsi

d. gambar model desain taman apotik hidup

e. cara menerapkan desain taman apotik hidup di lapangan.

3. Penyebaran kuesioner, dilakukan untuk mengukur tingkat manfaat sosialisasi yang dirasakan responden/khalayak sasaran.

Pengumpulan data terkat tingkat ketercapaian penyuluhan dari manfaat yang dirasakan khalayak sasaran dari hasil pembuatan desain taman apotik hidup dilakukan melalui penyebaran kuesioner, terdapat di Tabel I. Dari kuesioner yang terkumpul, dilakukan analisis data menggunakan perhitungan prosentase dari jumlah responden yang menjawab ya terhadap jumlah responden secara keseluruhan yang menjawab tiap pertanyaan pada kuesioner.

Tabel I. Kuesioner pengukuran tingkat manfaat penyuluhan dan model desain taman apotik hidup

\begin{tabular}{|c|c|c|c|}
\hline \multirow{2}{*}{ No } & \multirow{2}{*}{ Pernyataan } & \multicolumn{2}{|c|}{ Jawaban } \\
\hline & & Ya & Tidak \\
\hline 1 & $\begin{array}{l}\text { Pembuatan model desain taman apotik } \\
\text { hidup sangat bermanfaat sebagai } \\
\text { panduan penataan ta-man yang mejadi } \\
\text { lokasi model di kemudian hari }\end{array}$ & & \\
\hline 2 & $\begin{array}{l}\text { Penjelasan tentang model de-sain taman } \\
\text { apotik hidup mem-buka wawasan } \\
\text { untuk menata taman-taman apotik } \\
\text { hidup lainnya }\end{array}$ & & \\
\hline 3 & $\begin{array}{l}\text { Terkait dengan langkah untuk } \\
\text { mewujudkan model desain ta-man } \\
\text { apotik hidup, masyarakat memerlukan } \\
\text { pendampingan/ bimbingan dari tim } \\
\text { Pengabdian kepada Masyarakat (PkM) }\end{array}$ & & \\
\hline 4 & $\begin{array}{l}\text { Pembuatan model desain taman apotik } \\
\text { hidup dapat lebih meng-optimalkan } \\
\text { partumbuhan (per-tumbuhan tanaman } \\
\text { menjadi lebih baik) dan hasil dari ta- } \\
\text { naman apotik hidup yang di-tanam } \\
\text { (hasil lebih baik) }\end{array}$ & & \\
\hline 5 & $\begin{array}{l}\text { Dalam pengembangan pena-taan } \\
\text { taman-taman apotik hidup lainnya, } \\
\text { masyarakat } \quad \text { memerlu-kan } \\
\text { pendamingan/bimbingan dari tim PkM }\end{array}$ & & \\
\hline
\end{tabular}

\section{HASIL DAN PEMBAHASAN}

Program PkM yang dilaksanakan di RW 20, Desa Ciangsana, Nagrak diawali dengan survey untuk 
melakukan koordinasi sekaligus konsultasi untuk menentukan lokasi tapak yang akan dibuatkan model desain taman apotik hidup. Pada saat survey, juga dilakukan pengumpulan data terkait kebutuhan desain taman. Berdasarkan kesepakatan bersama, dilakukan penyusunan jadwal pelaksanaan penyuluhan terkait penjabaran langkah pembuatan model dan penjabaran model taman agar dapat diaplikasikan di lapangan. Gambar model desain taman apotik hidup dapat dilihat pada banner yang terdapat pada Gambar 1 .

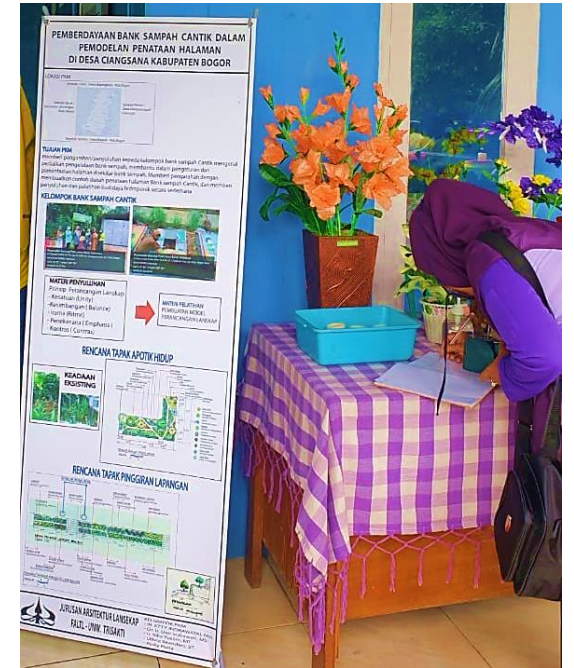

Gambar 1. Banner yang menggambarkan Model Desain Apotik Hidup

Pelaksanaan penyuluhan dilakukan di aula Bank Cantik dengan peserta, yang terdiri dari wakil dari kepengurusan dari Bank Cantik (RW 20) dan Bank Cinta (RW 21); wakil dari ibu-ibu PKK dari Bank Cantik dan Bank Cinta; serta ketua dan sekretaris RW 20.

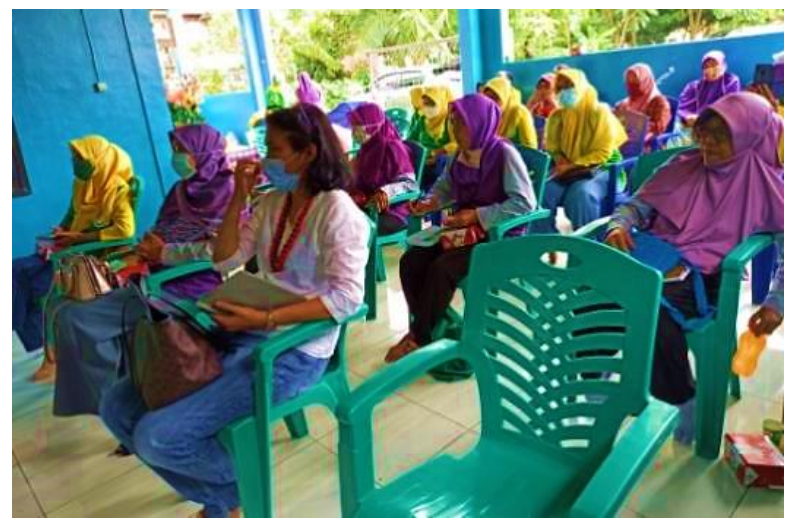

Gambar 2. Peserta PkM (perwakilan dari pengurus Bank Sampah, ibu-ibu PKK, serta Ketua dan Sekretaris RW 20)
Penjabaran materi penyuluhan yang dilakukan mendapat tanggapan yang baik. Ini karena peserta merasa bahwa materi yang terkait penjabaran langkah pembuatan model taman apotik hidup merupakan materi yang membekali peserta untuk membuat taman apotik hidup di pekarangan/halaman masing-masing (Gambar 3). Sementara penjabaran/gambar dari model desain dari taman apotik hidup (Gambar 5) merupakan wujud nyata yang dapat peserta lihat melalui penjelasan gambar sebagai hasil dari langkah pembuatan model.

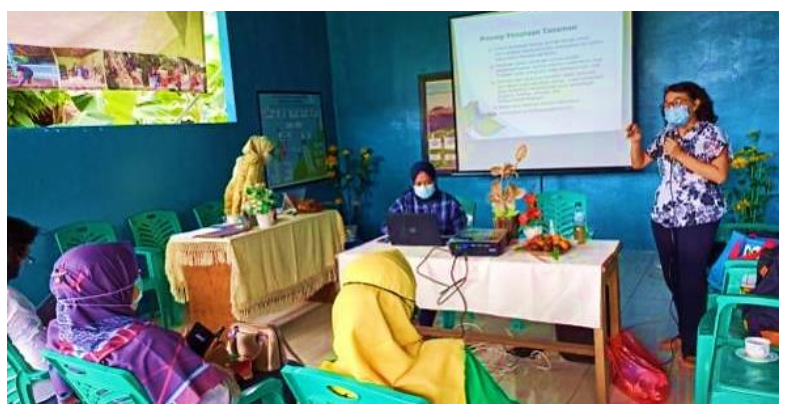

Gambar 3. Pelaksanaan Penyuluhan Terkait Proses Pembuatan Desain

Untuk tanaman obat dengan habitus perdu dan semak, dipilih sebagian tanaman yang telah ada pada tapak atau tanaman banyak dikenal masyarakat, diantaranya tanaman Kunyit (Curcuma longa), Serai Wangi (Cymbopogon nardus), Jahe (Zingiber officinale), Temulawak (Curcuma xanthorrhiza), Kencur (Kaempferia galanga), Lengkuas (Alpinia galanga), Sambiloto (Andrographis paniculata), Temu Kunci (Boesenbergia rotunda), Sambung Nyawa (Gynura procumbens), Lidah Buaya (Aloe vera), dan Kenikir (Cosmos caudatus). Untuk tanaman obat dengan habitus pohon, dipertahankan tanaman yang telah tumbuh pada tapak, yaitu Petai Cina (Leucaena leucocephala), Mengkudu (Morinda citrifolia), Coklat (Theobroma cacao L.), Nangka (Artocarpus heterophyllus), Ceremai (Phyllanthus acidus), Belimbing Wuluh (Averrhoa bilimbi), Mahkota Dewa (Phaleria macrocarpa), Pohon Kelor (Moringa oleifera), dan Jeruk Nipis (Citrus aurantiifolia). Untuk manfaat dari tanaman obat yang dipilih dapat dilihat pada Tabel II. 
Tabel II. Tanaman Obat dan Manfaatnya

\begin{tabular}{|c|c|c|}
\hline No & $\begin{array}{c}\text { Jenis } \\
\text { Tanaman }\end{array}$ & Manfaat \\
\hline 1 & $\begin{array}{l}\text { Kunyit } \\
\text { Curcuma } \\
\text { longa }\end{array}$ & $\begin{array}{l}\text { Obat gatal, gangguan hati, radang } \\
\text { umbai usus buntu, radang rahim, } \\
\text { keputihan, dan menghentikan } \\
\text { pendarahan (Widya \& Rizal, 2015) }\end{array}$ \\
\hline 2 & $\begin{array}{l}\text { Serai Wangi } \\
\text { Cymbopogon } \\
\text { nardus }\end{array}$ & $\begin{array}{l}\text { Obat gangguan pencernaan, } \\
\text { gangguan pada sistem saraf, } \\
\text { mencegah penyakit kanker, } \\
\text { menurunkan tekanan darah (Widya } \\
\text { \& Rizal, 2015). Juga mengobati nyeri } \\
\text { lambung, diare, obat sakit kepala, } \\
\text { batuk, penghangat badan, penurun } \\
\text { panas dan pengusir nyamuk } \\
\text { (Hendrik et al., 2013). }\end{array}$ \\
\hline 3 & $\begin{array}{l}\text { Jahe } \\
\text { Zingiber } \\
\text { officinale }\end{array}$ & $\begin{array}{l}\text { Mengatasi nyeri pada tulang (adanya } \\
\text { bahan aktif dari ekstrak) (Widya \& } \\
\text { Rizal, 2015). Juga mengobati penyakit } \\
\text { Hipoglikemi, Ostheoartritis, Gout, } \\
\text { Rhematoid Arthritis, Migrain, } \\
\text { Kardiovaskular, Hepatoprotektif, dan } \\
\text { penyakit pada sistem gastrointestinal } \\
\text { (Qamariah et al., 2019). }\end{array}$ \\
\hline 4 & $\begin{array}{l}\text { Temulawak } \\
\text { Curcuma } \\
\text { zanthorrhiza }\end{array}$ & $\begin{array}{l}\text { Obat sakit kuning, diare, lambung, } \\
\text { perut kembung, pegal-pegal, } \\
\text { mencegah penggumpalan darah, } \\
\text { menurunkan lemak darah, dan } \\
\text { memelihara kesehatan tubuh (Widya } \\
\text { \& Rizal, 2015). }\end{array}$ \\
\hline 5 & $\begin{array}{l}\text { Kencur } \\
\text { Kaempferia } \\
\text { galanga }\end{array}$ & $\begin{array}{l}\text { Obat batuk, infeksi bakteri, disentri, } \\
\text { sakit perut, asma, masuk angin, } \\
\text { penambah selera makan, tonikum, } \\
\text { dan anti jamur (Widya \& Rizal, 2015). }\end{array}$ \\
\hline 6 & $\begin{array}{l}\text { Lengkuas } \\
\text { Alpinia } \\
\text { galanga }\end{array}$ & $\begin{array}{l}\text { Obat penyakit reumatik, penyakit } \\
\text { kulit, penyakit limfa, diare, luka } \\
\text { dalam perut, tumor, mencagah } \\
\text { Radang, mengurangi } \\
\text { Pusing saat mabuk laut, } \\
\text { menambah nafsu makan (Widya \& } \\
\text { Rizal, 2015). }\end{array}$ \\
\hline 7 & $\begin{array}{l}\text { Sambiloto } \\
\text { Andrographis } \\
\text { paniculata }\end{array}$ & $\begin{array}{l}\text { Melindungi hati, menekan } \\
\text { pertumbuhan sel kanker (Widya \& } \\
\text { Rizal, 2015). }\end{array}$ \\
\hline 8 & $\begin{array}{l}\text { Temu kunci } \\
\text { Boesenbergia } \\
\text { rotunda }\end{array}$ & $\begin{array}{l}\text { Obat aphrodisiak, mengatasi ganguan } \\
\text { kolik (Taweechaisupapong et al., } \\
\text { 2010), bahan sauna (Silalahi et al., } \\
\text { 2015a) sebagai campuran minuman } \\
\text { tonik bagi ibu pasca melahirkan } \\
\text { (Silalahi et al., 2015b), anti-HIV-1 PR, } \\
\text { anti-inflammatori dan anti oksidatif } \\
\text { (Kim et al., 2013; Chahyadi et al., 2014), } \\
\text { analgesik, anti kanker (Nurrachma et } \\
\text { al., 2018), dan anti obesitas (Kim et al., } \\
\text { 2013), serta dikenal sebagai } \\
\text { antimikroba karena mengahambat } \\
\text { pertumbuhan fungi, khamir dan } \\
\text { bakteria (Chahyadi et al., 2014). }\end{array}$ \\
\hline 9 & $\begin{array}{l}\text { Sambung } \\
\text { Nyawa } \\
\text { Gynura } \\
\text { procumbens }\end{array}$ & $\begin{array}{l}\text { Obat kanker payudara dan kanker } \\
\text { darah (Winarto, 2004). }\end{array}$ \\
\hline 10 & $\begin{array}{l}\text { Lidah } \\
\text { Buaya } \\
\text { Aloe vera }\end{array}$ & $\begin{array}{l}\text { Anti oksidan dan anti penuaan } \\
\text { (Sianturi, 2019). }\end{array}$ \\
\hline 11 & $\begin{array}{l}\text { Kenikir } \\
\text { Cosmos } \\
\text { caudatus }\end{array}$ & $\begin{array}{l}\text { obat penguat tulang, lemah lambung, } \\
\text { dan penambah nafsu makan (Kusuma } \\
\text { et al., 2015). }\end{array}$ \\
\hline
\end{tabular}

Pada dasarnya banyak peserta yang berminat untuk hadir pada pelaksanaan program PkM ini. Namun, mengingat pelaksanaannya masih dalam situasi pandemik, di mana jumlah orang berkumpul untuk melaksanakan kegiatan bersama sangat dibatasi, maka jumlah peserta dibatasi hanya 20 orang (Gambar 3). Dengan keterbatasan ini, diharapkan peserta dapat berbagi ilmu dan membimbing ibu-ibu PKK yang lain atau masyarakat setempat.

Setelah materi PkM telah disampaikan dan diskusi telah dilaksanakan, dilakukan penyebaran kuesioner dan penyerahan gambar model desain taman apotik hidup ke ketua pengurus Bank Cantik (Gambar 4). Hasil dari penyebaran kuesioner diperoleh hasil bahwa $96 \%$ peserta merasa program ini sangat bermanfaat dan memerlukan pendampingan dalam mewujudkannya di lapangan.

Berdasarkan hasil kuesioner dan diskusi dengan pengurus Bank Sampah Cantik dan Cinta, akan dilakukan tindak lanjut berupa kerja sama yang akan memperkuat hubungan kerja antara Jurusan Arsitektur Lanskap dan Pengurus Bank Sampah di Desa Ciangsana. Dengan adanya hubungan kerja sama ini diharapkan Desa Ciangsana akan menjadi desa binaan jurusan Arsitektur Lanskap bagi penerapan programprogram PkM selanjutnya.

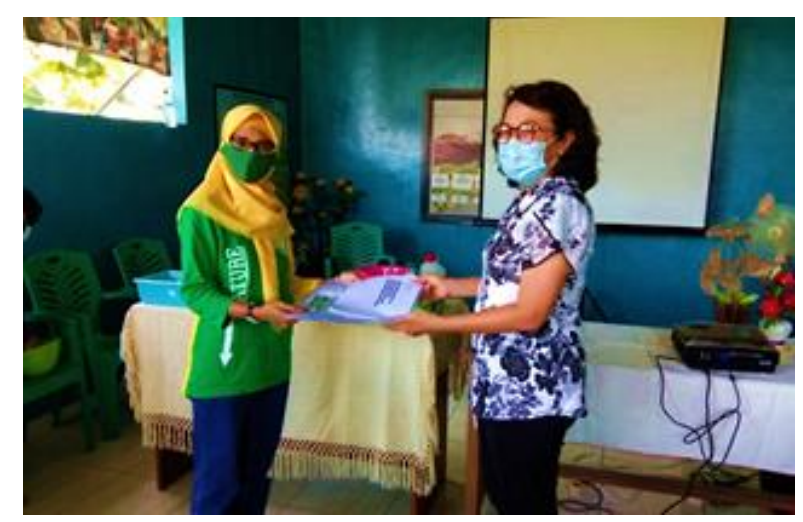

Gambar 4. Penyerahan Gambar Model Desain Apotik Hidup kepada Kepala Pengurus Bank Cantik 


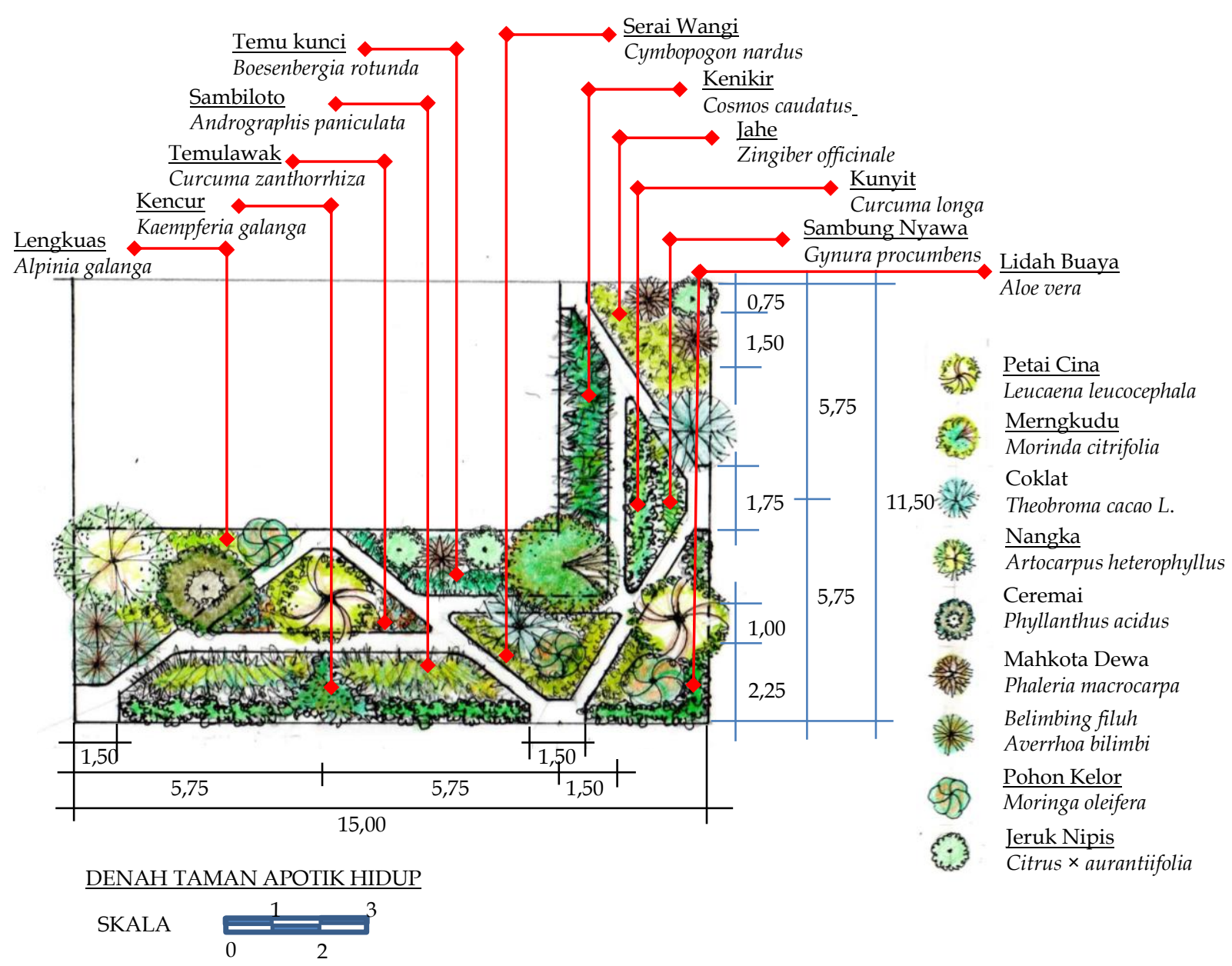

Gambar 5. Model Desain Taman Apotik Hidup

\section{KESIMPULAN}

Pembuatan model desain taman apotik hidup untuk masyarakat RW 20 yang telah memiliki Bank Sampah Cantik mendapat tanggapan yang baik dari masyarakat setempat. Program ini sesuai dengan kebutuhan masyarakat, terutama dalam memanfaatkan hasil pengolahan sampah dapur (sampah organik) yang berupa kompos sebagai campuran media tanam dari tanaman obat. Upaya ini juga sekaligus dapat meningkatkan kesehatan masyrakat setempat dan pelestarian tanaman obat yang dicanangkan oleh pemerintah. Melalui pelaksanaan program PkM ini dipesankan kepada masyrakat agar dapat meniru dan menerapkannya di pekarangan rumah masing-masing. Pengurus Bank Sampah Cantik dan Cinta juga menginginkan adanya pendampingan dalam pembuatan dan penataan taman apotik hidup selanjutnya. Desa Ciangsana, khususnya RW 20 (Bank Sampah Cantik) dan RW 21 (Bank Sampah Cinta) akan dijadikan desa binaan bagi pelaksanaan program PKM selanjutnya.

\section{REFERENSI}

Chahyadi, A., Hartati, R., Wirsutisna, K.R., Elfahmi. 2014. Boesenbergia Pandurata Roxb., An Indonesian Medicinal Plant: Phytochemistry, Biological Activity, Plant Biotechnology. Procedia Chemistry. 13:13-37. https://doi.org/10.1016/j.proche.2014.12.003

Dahlianah, I. 2015. Pemanfaatan Sampah Organik Sebagai Bahan Baku Pupuk Kompos Dan Pengaruhnya Terhadap Tanaman Dan Tanah. Klorofil.

10(1):10-13. https://doi.org/10.32502/jk.v10i1.190 
Djabbar, A., Musdalipah, Nurwati, A. 2017. Studi Pengetahuan, Sikap dan Tindakan Terhadap Penggunaan Obat Tradisional Bagi Masyarakat di Desa Sabi-Sabila Kecamatan Mowewe Kabupaten Kolaka Timur. Pharmauho: Jurnal Farmasi, Sains, dan Kesehatan. 3(1):19-22.

http://dx.doi.org/10.33772/pharmauho.v3i1 .3448

Gunarto, A. 2012. Perencanaan Taman Obat Herbalia (TOBA) Dalam Penataan Halaman Puskesmas. Jurnal Rekayasa Lingkungan. 8(1):27-41.

https://doi.org/10.29122/jrl.v8i1.1977

Hendrik, W.G., Erwin, Panggabean, A.S. 2013. Pemanfaatan Tumbuhan Serai Wangi (Cymbopogon nardus (L.) Rendle) Sebagai Antioksidan Alami. Jurnal Kimia Mulawarman. 10(2):74-79.

Hikmat, A., Zuhud, E.A.M., Siswoyo, Sandra, E., Sari, R.K. 2011. Revitalisasi konservasi tumbuhan obat keluarga (toga) guna meningkatkan kesehatan dan ekonomi keluarga mandiri di desa Contoh Lingkar Kampus IPB Darmaga Bogor. Jurnal Ilmu Pertanian Indonesia. 16(2):7180.

Karo-Karo, U. 2010. Pemanfaatan Tanaman Obat Keluarga di Kelurahan Tanah 600, Medan. Kesmas: Jurnal Kesehatan Masyarakat Nasional (National Public Health Journal). 4(5):195-202. http://dx.doi.org/10.21109/kesmas.v4i5.169

Kim, D.Y., Kim, M.S., Sa, B.K., Kim, M.B., Hwang, J.K. 2012. Boesenbergia pandurata attenuates dietinduced obesity by activating AMP-activated protein kinase and regulating lipid metabolism. International Journal of Molecular Sciences. 13(1):994-1005.

https://doi.org/10.3390/ijms13010994

Kusuma, I.J.D., Prasetyorini, Wardatun, S. 2015. Toksisitas Ekstrak Daun Kenikir (Cosmos Caudatus Kunth) Dengan Perbedaan Metode Dan Jenis Pelarut Berbeda. Jurnal Online Mahasiswa (JOM) Bidang Farmasi. 1(1):1-9.

Mulyadi, A.D.A. 2011. Aplikasi Prinsip-Prinsip Desain Lansekap Taman Balekambang. Skripsi. Surakarta: Universitas Sebelas Maret.

Mulyani, H., Widyastuti, S.H., Ekowati, V.I. 2016. Tumbuhan Herbal Sebagai Jamu Pengobatan
Tradisional Terhadap Penyakit Dalam Serat Primbon Jampi Jawi Jilid I. Jurnal Penelitian Humaniora. 21(2):73-91.

Nurrachma, M.Y., Fadliyah, H., Meiyanto, E. 2018. Fingerroot (Boesenbergia pandurata): A Prospective Anticancer Therapy. Indonesian Journal of Cancer Chemoprevention. 9(2):102-109. http://dx.doi.org/10.14499/indonesianjcanc hemoprev9iss2pp102-109

Qamariah, N., Handayani, R., Novaryatiin, S. 2019. Peningkatan Pengetahuan dan Keterampilan Ibu Rumah Tangga dalam Pengolahan Tanaman Obat Keluarga (TOGA) sebagai Ramuan Obat Tradisional. PengabdianMu: Jurnal Imiah Pengabdian kepada Masyarakat. 4(1):50-54.

https://doi.org/10.33084/pengabdianmu.v4i 1.692

Sianturi, C.Y. 2019. Manfaat Lidah Buaya Sebagai Anti Penuaan Melalui Aktivitas Antioksidan. Essential: Essence of Scientific Medical Journal. 17(1):34-38.

Silalahi, M., Nisyawati, Walujo, E.B., Supriatna, J., Mangunwardoyo, W. 2015a. The local knowledge of medicinal plants trader and diversity of medicinal plants in the Kabanjahe traditional market, North Sumatra, Indonesia. Journal of Ethnopharmacology. 175:432-443. https://doi.org/10.1016/j.jep.2015.09.009

Silalahi, M., Supriatna, J., Walujo, E.B., Nisyawati, N. 2015b. Local knowledge of medicinal plants in sub-ethnic Batak Simalungun of North Sumatra, Indonesia. Biodiversitas. 16(1):44-54. https://doi.org/10.13057/biodiv/d160106

Simonds, J.O., Starke, B. 2006. Landscape Architecture: A Manual of Environmental Planning and Design $4^{\text {th }}$ Edition. New York: McGraw-Hill Professional

Sumarni. 2013. "Intervensi Pemerintah" Antara Kebutuhan Dan Penolakan Di Bidang Ekonomi. Economica: Jurnal Program Studi Pendidikan Ekonomi STKIP PGRI Sumatera Barat. 1(2):45-60. https://doi.org/10.22202/economica.2013.v1 .i2.118

Taweechaisupapong S, Singhara S, Lertsatitthanakorn P, Khunkitti W. 2010. Antimicrobial effects of Boesenbergia pandurata and Piper sarmentosum leaf extracts on planktonic cells 
and biofilm of oral pathogens. Pakistn Journal of Pharmaceutical Sciences. 23(2):224-231.

Widya, T.W., Rizal, M. 2015. Upaya Pemberdayaan Apotik Hidup di Perkotaan Melalui Deskripsi dan Manfaat Tanaman Obat. Prosiding Seminar Nasional Masyarakat Biodiversitas Indonesia. 1(8): 1890-1895.

https://doi.org/10.13057/psnmbi/m010823

Winarto, W.P., Karyasari, T. 2004. Sambung Nyawa: Budi daya dan pemanfaatan untuk obat. Jakarta: Penebar Swadaya 